\title{
PERTIMBANGAN PEMBELIAN OLEH-OLEH \\ PADA RUTE PERJALANANAN WISATAWAN \\ MENGGUNAKAN TECHNIQUE FOR OTHERS PREFERENCE BY SIMILARITY TO IDEAL SOLUTION (TOPSIS)
}

\author{
Oliver Samuel Simanjuntak, Budi Santosa, Muhammad Bagus Prasetyo \\ Program Studi Teknik Informatika UPN "Veteran" Yogyakarta \\ e-mail: oliver.simanjuntak@upnyk.ac.id ${ }^{1}$, dissan@upnyk.ac.id ${ }^{2}$, bagusprasetyo0856@gnail.com $^{3}$
}

\begin{abstract}
The era of modernization has an impact on the needs of society, namely the needs of people doing their work quickly and easily. In particular tourists, tourists who visit a region eager to quickly and easily in search for souvenirs. In the search for souvenirs, tourists experience obstacles in the determination of the location of shops and souvenirs Tourists should look for souvenir shops manually. Mobile apps are one of the most commonly used information-seeking solutions, as mobile apps can be useful wherever they are and when. Availability of mobile applications are also often used by the public to find the location of a place or destination using Maps. In addition along with the development of technology, now mobile applications are also utilized in the process of buying and selling online. This makes it easy for the community to help, as well as complete their work properly, and practically. This Android-based app is built using java programming language by utilizing TOPSIS (Technique For Others Preference by Similarity to Ideal Solution) method to give consideration to user, and utilize GoogleMaps API. With this application the tourists can find souvenir shops and souvenirs simultaneously based on travel routes. In addition, this application, giving advantage to the owner of gift shop to sell souvenirs online. And some features that support the process of buying and selling.
\end{abstract}

Keywords: Souvenirs, Tourists, TOPSIS, GoogleMaps API, Trip Route, Android

\section{Abstrak}

Era modernisasi membawa dampak terhadap kebutuhan masyarakat, yaitu kebutuhan masyarakat melaksanakan pekerjaannya secara cepat dan mudah. Pada khususnya wisatawan, wisatawan yang mengunjungi suatu wilayah berkeinginan cepat dan mudah dalam pencarian oleh-oleh. Dalam pencarian oleh-oleh, wisatawan mengalami kendala dalam penentuan lokasi toko dan oleh-oleh Wisatawan harus mencari toko oleh-oleh secara manual. Aplikasi mobile merupakan salah satu solusi dalam pencarian informasi yang sering digunakan, karena aplikasi mobile dapat berguna dimanapun berada dan kapanpun waktunya. Tersedianya aplikasi mobile juga sering dimanfaatkan masyarakat untuk mencari lokasi suatu tempat atau tujuan menggunakan Maps. Selain itu seiring dengan perkembangan teknologi, sekarang aplikasi mobile juga di manfaatkan dalam proses jualbeli secara online. Hal ini memberikan kemudahan bagi masyarakat dalam membantu, serta menyelesaikan pekerjaannya secara tepat, dan praktis. Aplikasi berbasis Android ini dibangun menggunakan bahasa pemprograman java dengan memanfaatkan metode TOPSIS (Technique For Others Preference by Similarity to Ideal Solution) untuk memberikan pertimbangan kepada pengguna, serta memanfaatkan GoogleMaps API. Dengan aplikasi ini para wisatawan dapat menemukan toko oleh-oleh dan oleh-oleh secara bersamaan berdasarkan rute perjalanan. Selain itu, aplikasi ini,memberikan keuntungan kepada para pemilik toko oleh-oleh untuk menjual oleh-oleh secara online. Serta beberapa fitur yang menunjang proses jual-beli.

Kata kunci: Oleh-oleh, Wisatawan, TOPSIS, GoogleMaps API, Rute Perjalanan, Android

\section{PENDAHULUAN}

Era modernisasi membawa dampak terhadap kebutuhan masyarakat untuk mengerjakan sesuatu secara bersamaan sehingga pola pikir dan gaya hidup masyarakat menuntut segala pekerjaan menjadi praktis dan instan. Praktis dan instan merupakan dua hal yang tidak bisa dipisahkan dari keinginan manusia, karena mempercepat dan memudahkan manusia dalam melakukan segala 
aktivitas. Tetapi tidak semua hal bisa di kerjakan secara praktis dan instan. Hal ini dapat dilihat dari sudut pandang wisatawan, yaitu saat wisatawan berkunjung ingin membeli oleh-oleh khas jogja. Wisatawan mengalami kendala untuk mencari lokasi toko dan oleh-oleh yang diinginkan. Wisatawan harus mencari toko oleh-oleh secara manual dan random. Terlebih ketika wisatawan hanya memiliki waktu yang singkat dan bergagas untuk segera pulang, Selain itu, proses jual-beli di toko oleh-oleh memakan waktu yang relatif lama, sering terjadi proses antrian pembeli oleh-oleh, sehingga membuang waktu. Pada akhirnya kebanyakan wisatawan memutuskan untuk tidak membawa oleholeh, dan menganggap berbelanja oleh-oleh adalah suatu kegiatan yang membuang waktu, tidak instan, dan tidak praktis.

Perkembangan teknologi informasi sangat cepat, seiring dengan kebutuhan akan informasi dan pertumbuhan tingkat kecerdasan manusia. Saat ini telah banyak sistem informasi untuk menunjang dan menyelesaikan suatu permasalahan yang ada di lingkungan masyarakat. Aplikasi mobile merupakan salah satu solusi dalam mencari informasi yang sering digunakan, karena aplikasi mobile dapat berguna dimanapun berada dan kapanpun waktunya. Tersedianya aplikasi mobile juga sering dimanfaatkan masyarakat untuk mencari lokasi suatu tempat atau tujuan menggunakan Maps. Selain itu seiring dengan perkembangan teknologi, sekarang aplikasi mobile juga di manfaatkan dalam proses jual-beli secara online. Hal ini memberikan kemudahan bagi masyarakat dalam membantu, serta menyelesaikan pekerjaannya secara tepat, dan praktis.

Berdasarkan masalah peneliti bermaksud untuk membangun sebuah Aplikasi yang mengimplementasikan metode TOPSIS sebagai alternatif untuk memberikan pertimbangan dalam memilih toko oleh-oleh terbaik dan mencari toko oleh-oleh khas jogja berdasarkan rute perjalanan berbasis android. Sehingga memudahkan wisatawan untuk mencari toko oleh-oleh berdasarkan rute perjalanan yang akan dituju, serta beberapa fitur yang menunjang proses jual-beli oleh-oleh. Dengan adanya Aplikasi ini diharapkan dapat memberikan keuntungan yang lebih besar kepada para penjual dan memudahkan wisatawan untuk mendapatkan kebutuhannya.

\section{TINJAUAN PUSTAKA}

\subsection{Google Maps API}

Google Maps API adalah sebuah layanan (service) yang diberikan oleh Google kepada para pengguna untuk memanfaatkan Google Map dalam mengembangkan aplikasi. Google Maps API menyediakan beberapa fitur untuk memanipulasi peta, dan menambah konten melalui berbagai jenis services yang dimiliki, serta mengijinkan kepada pengguna untuk membangun aplikasi enterprise di dalam sebuah website (Mahdia \& Noviyanto, 2013). Berikut adalah beberapa fitur yang tersedia di Google Maps API :

1. Google Place API for Android adalah API yang berfungsi sebagai database data geografis suatu lokasi dari seluruh dunia.

2. Google Maps Direction API adalah API yang berfungsi untuk menemukan jalan, dan waktu tempuh dengan alat tranportasi berupa mobil, kereta, sepeda, dan berjalan kaki.

3. Google Maps Geocoding API adalah API yang berfungsi untuk konversi alamat menjadi koordinat geografis.

Google Maps Android API, secara otomatis menangani akses ke server Google Maps, mengunduh data, menampilkan peta, dan merespons gerakan peta, API untuk menambahkan marker, poligon, dan overlay ke peta dasar, serta mengubah tampilan area peta tertentu ke pengguna. Semua objek memberikan informasi tambahan tentang lokasi peta, dan memungkinkan interaksi pengguna dengan peta.

\subsection{TOPSIS}

TOPSIS (Technique For Others Preference by Similarity to Ideal Solution) merupakan salah satu metode dalam memecahkan masalah multikriteria (Rahmayani A. dan Isa Irawan M., 2016). TOPSIS adalah pengambilan keputusan multikriteria atau alternatif pilihan yang merupakan alternatif yang mempunyai jarak terkecil dari solusi ideal negatif dari sudut pandang geometris dengan menggunakan jarak Euclidean untuk menentukan kedekatan relatif dari suatu alternatif dengan solusi optimal. Namun, alternatif yang mempunyai dari solusi ideal positif, tidak harus mempunyai jarak terbesar dari solusi ideal negatif. Maka dari itu, TOPSIS mempetimbangkan keduanya, jarak terhadap solusi ideal positif dan jarak terhadap solusi ideal negatif secara bersamaan. Solusi optimal dalam metode TOPSIS didapat dengan menentukan kedekatan relatif suatu altenatif terhadap solusi ideal positif. TOPSIS memperhatikan jarak ke solusi ideal positif maupun jarak ke solusi ideal negatif dengan mengambil hubungan kedekatan menuju solusi ideal. Dengan melakukan perbandingan pada keduanya, urutan pilihan dapat ditentukan. Berikut ini adalah matriks $\mathrm{C}$ yang memiliki $\mathrm{m}$ 
alternatif dengan $n$ kriteria, dimana $x_{i j}$ adalah pengukuran pilihan dari alternatif ke-i dalam hubungannya dengan kriteria ke-j.

$$
C=\left[\begin{array}{cccccc}
x_{11} & x_{12} & x_{13} & \cdot & \cdot & x_{1 n} \\
x_{21} & x_{22} & x_{23} & \cdot & \cdot & x_{2 n} \\
x_{31} & x_{32} & x_{33} & \cdot & \cdot & x_{3 n} \\
\cdot & \cdot & \cdot & & & \cdot \\
\cdot & \cdot & \cdot & & & \cdot \\
x_{m 1} & x_{m 2} & x_{m 3} & . & . & x_{m n}
\end{array}\right]
$$

Langkah-langkah yang dilakukan dalam penyelesaian masalah menggunakan metode TOPSIS adalah sebagai berikut :

1. Normalisasi Matriks Keputusan. Setiap elemen pada matriks C dinormalisasi untuk mendapatkan matriks normalisasi. Setiap normalisasi dari nilai $r_{i j}$ dapat dilakukan dengan perhitungan sebagai berikut :

$$
\mathrm{r}_{\mathrm{ij}}=\frac{x_{i j}}{\sqrt{\sum_{i=1}^{m} x_{i j}^{2}}}
$$

2. Pembobotan Pada Matriks yang telah dinormalisasi. Secara matematis, weighted normalised matrix ini dapat diperoleh dengan rumus berikut ini:

Dimana :

$$
y_{i j}=w_{j} \cdot r_{i j}
$$

$\mathrm{y}_{\mathrm{ij}} \quad$ : matriks normalisasi terbobot [i][j]

$\mathrm{w}_{\mathrm{j}} \quad$ : vektor bobot [j]

$r_{i j} \quad$ : matriks ternormalisasi [i][j]

3. Menentukan Solusi Ideal dan Solusi Ideal Negatif. Solusi ideal dinotasikan dengan A+ dan solusi ideal negatif dinotasikandengan A-. Untuk lebih jelasnya, dapat dilihat dibawah ini: dengan $\mathrm{i}=1,2, \ldots, \mathrm{m}$ dan $\mathrm{j}=1,2, \ldots, \mathrm{n}$

$$
\begin{aligned}
& A^{+}=\left(y_{1}^{+}, y_{2}^{+}, \ldots y_{n}^{+}\right) \\
& A^{-}=\left(y_{1}^{-}, y_{2}^{-}, \ldots y_{n}^{-}\right)
\end{aligned}
$$

Dimana $y_{j}^{+}$adalah : $\max \mathrm{y}_{\mathrm{ij}}$, jika j adalah atribut keuntungan (benefit) $\min \mathrm{y}_{\mathrm{ij}}$, jika $\mathrm{j}$ adalah atribut biaya (cost) $y_{j}^{-}$adalah: $\quad$ min $y_{i j}$, jika j adalah atribut keuntungan (benefit) max $\mathrm{y}_{\mathrm{ij}}$, jika $\mathrm{j}$ adalah atribut biaya (cost). Pembangunan A+ dan A- adalah untuk mewakili alternatif yang most preferable ke solusi ideal dan yang least preferable secara berurutan.

4. Menghitung Separation Measure. Separation measure ini merupakan pengukuran jarak dari suatu alternatif ke solusi ideal dan solusi ideal negatif. Perhitungan matematisnya adalah sebagai berikut:

a. Rumus pengukuran jarak solusi ideal positif $\left(\mathrm{S}^{+}\right)$

$$
\mathrm{S}^{+}=\sqrt{\sum_{j=1}^{n}\left(y_{i j}-y_{j}^{+}\right)^{2}} ; \mathrm{i}=1,2, \ldots, \mathrm{n}
$$

b. Rumus pengukuran jarak solusi ideal negatif $\left(\mathrm{S}^{-}\right)$

$$
\mathrm{S}^{-}=\sqrt{\sum_{j=1}^{n}\left(y_{i j}-y_{j}^{-}\right)^{2}} ; \mathrm{i}=1,2, \ldots, \mathrm{n}
$$

5. Menghitung Kedekatan Relatif dengan solusi ideal. Kedekatan relatif dari alternatif $A_{i}$ dengan solusi ideal $A_{+}$direpresentasikan dengan:

$$
\mathrm{C}_{\mathrm{i}}^{*}=\frac{S_{i}^{-}}{S_{i}^{-}+S_{i}^{+}}
$$

dimana $0<C_{i}^{*}<1$ dan $i=1,2,3, \ldots$, n dikatakan alternatif Ai dekat dengan solusi ideal apabila $C_{i}^{*}$ mendekati 1. Jadi $C_{i}^{*}=1$ jika $A_{i}=A_{+}$dan $C_{i}^{-}=0$ jika $A_{i}=A^{-}$.

6. Mengurutkan Alternatif. Alternatif dapat diurutkan berdasarkan urutan $C_{i}^{*}$. Sehingga alternatif yang memiliki jarak terpendek terhadap solusi ideal adalah alternatif yang terbaik. 


\section{ANALISIS DAN PERANCANGAN}

\subsection{Arsitektur Sistem}

Untuk arsitektur dari aplikasi pencarian oleh-oleh khas jogja berbasis android. User yang sudah meng-install aplikasi, bisa melihat informasi oleh-oleh dan toko oleh-oleh serta pemesanan oleh-oleh secara realtime, dari smartphone / tablet. Informasi yang tampil di aplikasi akan sama seperti yang di server, karena data yang tampil diambil dari server secara langsung. Aplikasi yang berjalan di android membutuhkan koneksi internet untuk mengambil data yang ada di server. Admin dan operator hanya perlu menginputkan informasi melalui aplikasi berbasis web, maka pengguna akan mendapatkan update secara langsung untuk informasi baru yang telah diinputkan. Arsitektur sistem dapat dilihat pada gambar 1 .

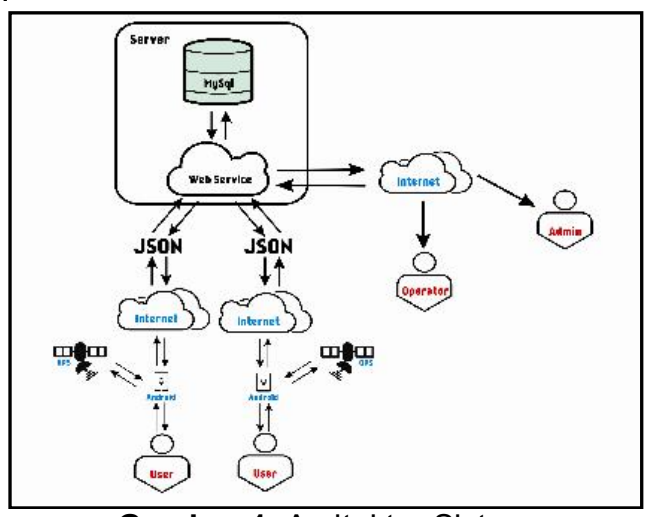

Gambar 1. Arsitektur Sistem

\subsection{Representasi Metode TOPSIS}

Pada sub bab ini akan dijelaskan data hasil wawancara dan diberikan contoh perhitungan metode TOPSIS dari proses yang dilakukan oleh sistem.

\subsubsection{Akuisisi Bobot TOPSIS}

Satu data penunjang yang diperlukan untuk memenuhi kebutuhan dalam proses perhitungan maka dibuat suatu angket yang diisi dengan cara wawancara kepada para pegawai toko. Pengolahan data angket untuk mendapatkan nilai bobot kepentingan pada setiap kriteria menggunakan nilai bobot kepentingan pada tabel 1. Data hasil survei terhadap 15 toko oleh-oleh.

Tabel 1. Tingkat Bobot Kepentingan Kriteria

\begin{tabular}{|c|c|}
\hline Nilai & Keterangan Nilai \\
\hline 1 & Sangat Rendah \\
\hline 2 & Rendah \\
\hline 3 & Cukup \\
\hline 4 & Tinggi \\
\hline 5 & Sangat Tinggi \\
\hline
\end{tabular}

\subsubsection{Simulasi Perhitungan TOPSIS}

Pada perhitungan ini peneliti mengambil contoh kasus 2 kandidat toko oleh-oleh yang akan diseleksi untuk mendapatkan alternatif toko terbaik. Pada Tabel 2 merupakan tabel nilai kepentingan terhadap setiap kriteria yang dinilai dari (satu) sampai 5 (lima) dari data survei. Nilai kepentingan untuk setiap kriteria adalah sebagai berikut : Diketahui toko Lezat Rasa(A1) memiliki Rating Toko $(\mathrm{C} 1)=4$, Kelengkapan Barang $(C 2)=2$, dan Jumlah penjualan $(\mathrm{C} 3)=5$. Dan toko Enak(A2) memiliki Rating Toko $(\mathrm{C} 1)=2$, Kelengkapan Barang $(\mathrm{C} 2)=3$, dan Jumlah penjualan $(\mathrm{C} 3)=2$. Dengan bobot $(\mathrm{w})$ setiap kriteria $\mathrm{C} 1=4 ; \mathrm{C} 2=2 ; \mathrm{C} 3=2$;

Tabel 2. Data toko untuk setiap kriteria

\begin{tabular}{|l|l|l|l|l|}
\hline No & Nama Toko & C1 & C2 & C3 \\
\hline $\mathbf{1}$ & A1 & 4 & 2 & 5 \\
\hline $\mathbf{2}$ & A2 & 2 & 3 & 2 \\
\hline
\end{tabular}

a. Perhitungan matriks normalisasi adalah sebagai berikut : 


$$
\begin{aligned}
& \mathrm{r}_{\mathrm{ij}}=\frac{X_{i j}}{\sqrt{\sum_{i=1}^{m} x_{i j}^{2}}} \\
& \mathrm{r}_{\mathrm{A} 1, \mathrm{C} 1}=\frac{X_{C 1}}{\sqrt{\sum_{i=1}^{m} x_{c 1}^{2}}}=\frac{4}{\sqrt{(4)^{2}+(2)^{2}}}=0,894427191 \\
& \mathrm{r}_{\mathrm{A} 1, \mathrm{C} 2}=\frac{X_{c 2}}{\sqrt{\sum_{i=1}^{m} x_{c 2}^{2}}}=\frac{2}{\sqrt{(2)^{2}+(3)^{2}}}=0,554700196 \\
& \mathrm{r}_{\mathrm{A} 1, \mathrm{C} 3}=\frac{X_{c 3}}{\sqrt{\sum_{i=1}^{m} x_{C 3}^{2}}}=\frac{5}{\sqrt{(5)^{2}+(2)^{2}}}=0,928476691 \\
& \mathrm{r}_{\mathrm{A} 2, \mathrm{C} 1}=\frac{X_{C 1}}{\sqrt{\sum_{i=1}^{m} x_{c 1}^{2}}}=\frac{2}{\sqrt{(4)^{2}+(2)^{2}}}=0,447213595 \\
& \mathrm{r}_{\mathrm{A} 2, \mathrm{C} 2}=\frac{X_{c 2}}{\sqrt{\sum_{i=1}^{m} x_{C 2}^{2}}}=\frac{3}{\sqrt{(2)^{2}+(3)^{2}}}=0,832050294 \\
& \mathrm{r}_{\mathrm{A} 2, \mathrm{C} 3}=\frac{X_{c 3}}{\sqrt{\sum_{i=1}^{m} x_{c 3}^{2}}}=\frac{2}{\sqrt{(5)^{2}+(2)^{2}}}=0,371390676
\end{aligned}
$$

b. Perhitungan Matriks Ternormalisasi Terbobot adalah Sebagai Berikut

$$
\begin{aligned}
& y_{i j}=w_{j} \cdot r_{i j} \\
& y_{A 1, C 1}=w_{C 1} \cdot r_{A 1, C 1}=4 \cdot 0,894427191=3,577708764 \\
& y_{A 1, C 2}=w_{C 2} \cdot r_{A 1, C 2}=2 \cdot 0,554700196=1,109400392 \\
& y_{A 1, C 3}=w_{C 3} \cdot r_{A 1, C 3}=2 \cdot 0,928476691=1,856953382 \\
& y_{A 2, C 1}=w_{C 1} \cdot r_{A 2, C 1}=4 \cdot 0,447213595=1,788854382 \\
& y_{A 2, C 2}=w_{C 2} \cdot r_{A 2, C 2}=2 \cdot 0,832050294=1,664100589 \\
& y_{A 2, C 3}=w_{C 3} \cdot r_{A 2, C 3}=2 \cdot 0,371390676=0,742781353
\end{aligned}
$$

c. Menentukan Solusi Ideal Positif dan Solusi Ideal Negatif. Selanjutnya nilai matriks keputusan ternormalisasi terbobot digunakan untuk menentukan nilai $A^{+}$(solusi ideal positif) dan nilai $A^{-}$ (solusi ideal positif), nilai dapat dilihat pada tabel 3.

Tabel 3. Solusi ideal positif dan solusi ideal negatif

\begin{tabular}{|l|c|c|c|}
\hline & $\mathbf{C 1}$ & $\mathbf{C 2}$ & $\mathbf{C 3}$ \\
\hline $\mathbf{A}^{+}$ & 3,57770876 & 1,664100589 & 1,856953382 \\
\hline $\mathbf{A}^{-}$ & 1,78885438 & 1,109400392 & 0,742781353 \\
\hline
\end{tabular}

d. Menghitung Jarak Solusi Ideal Positif dan Jarak Solusi Ideal Negatif. Selanjutnya memperhitungkan jarak solusi ideal positif $\left(\mathrm{S}^{+}\right)$dan negatif $\left(\mathrm{S}^{-}\right)$, adalah sebagai berikut :

$$
\begin{aligned}
& \mathrm{S}^{+}=\sqrt{\sum_{j=1}^{n}\left(y_{i j}-y_{j}^{+}\right)^{2}} \\
& \mathrm{~S}^{+}{ }_{\mathrm{A} 1}=\sqrt{\left(\left(y_{A 1, C 1}-y_{C 1}^{+}\right)^{2}+\left(y_{A 1, C 2}-y_{C 2}^{+}\right)^{2}+\left(y_{A 1, C 3}-y_{C 3}^{+}\right)^{2}\right)} \\
& \mathrm{S}^{+}{ }_{\mathrm{A} 1}=0,5547 \\
& \mathrm{~S}^{+}=\sqrt{\left(\left(y_{A 2, C 1}-y_{C 1}^{+}\right)^{2}+\left(y_{A 2, C 2}-y_{C 2}^{+}\right)^{2}+\left(y_{A 2, C 3}-y_{C 3}^{+}\right)^{2}\right)} \\
& \mathrm{S}^{+}{ }_{\mathrm{A} 2}=2,10746 \\
& \mathrm{~S}^{-}=\sqrt{\sum_{j=1}^{n}\left(y_{i j}-y_{j}^{-}\right)^{2}} \\
& \mathrm{~S}^{-}{ }_{\mathrm{A} 1}=\sqrt{\left(\left(y_{A 1, C 1}-y_{C 1}^{-}\right)^{2}+\left(y_{A 1, C 2}-y_{C 2}^{-}\right)^{2}+\left(y_{A 1, C 3}-y_{C 3}^{-}\right)^{2}\right)} \\
& \mathrm{S}^{-}{ }_{\mathrm{A} 1}=2,10746 \\
& \mathrm{~S}^{-}{ }_{\mathrm{A} 2}=\sqrt{\left(\left(y_{A 2, C 1}-y_{C 1}^{-}\right)^{2}+\left(y_{A 2, C 2}-y_{C 2}^{-}\right)^{2}+\left(y_{A 2, C 3}-y_{C 3}^{-}\right)^{2}\right)} \\
& \mathrm{S}^{-}{ }_{\mathrm{A} 2}=0,5547
\end{aligned}
$$

e. Menghitung Kedekatan Relatif dengan Solusi Ideal

$$
\begin{aligned}
& \mathrm{C}_{\mathrm{i}}^{*}=\frac{S_{i}^{-}}{S_{i}{ }^{-}+S_{i}{ }^{+}} \\
& \mathrm{C}_{\mathrm{A} 1}{ }^{*}=\frac{S_{A 1}{ }^{-}}{S_{A 1^{-}+S_{A 1}{ }^{+}}}=\frac{2,10746}{2,10746+0,5547}=0,79164 \\
& \mathrm{C}_{\mathrm{A} 2}{ }^{*}=\frac{S_{A 2}{ }^{-}}{S_{A 2^{-}+S_{A 2}{ }^{+}}}=\frac{0,5547}{0,5547+2,10746}=0,20836
\end{aligned}
$$


Maka dari perhitungan diatas dapat disimpulkan bahwa alternatif toko yang terbaik berdasarkan 3 kriteria adalah toko oleh-oleh lezat rasa (A1).

\subsection{Analisis Aplikasi Pada Sisi Client}

Dari analisis sistem, berikut adalah analisis sistem dari aplikasi, terdiri dari Use Case Diagram, Class Diagram, Sequence Diagram dan Activity Diagram.

\subsubsection{Use Case Diagram}

Pada tahapan ini menjelaskan mengenai aksi yang dapat dilakukan oleh user yang digambarkan di use case diagram diagram pada gambar 2.

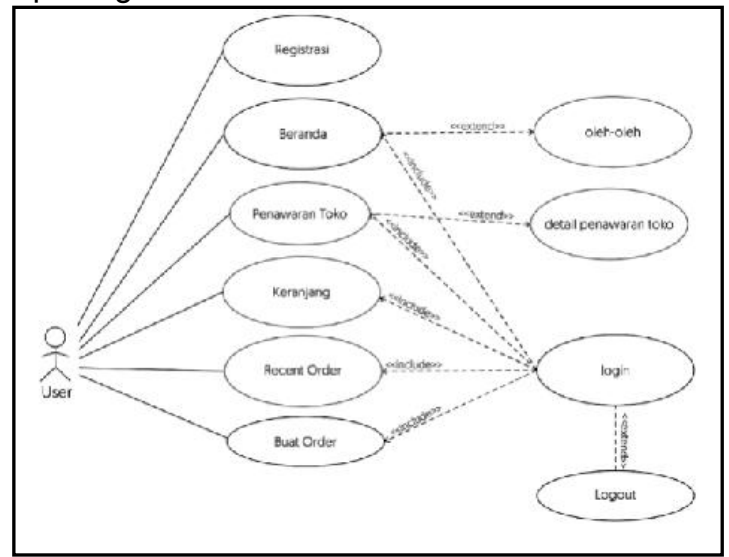

Gambar 2. Use Case Diagram

Pada Use Case ini dijelaskan terdapat 1 aktor, yaitu wisatawan. Wisatawan dapat melakukan 6 aktifitas atau kegiatan, yaitu registrasi, beranda, orderan toko, pembayaran, cari oleh-oleh, cari toko, cari toko berdasarkan rute perjalanan. Agar bisa melakukan 6 aktifitas, user harus login terlebih dahulu.

\subsubsection{Class Diagram}

Pada tahap ini akan diperinci lagi hasil dari analisis pada diagram use case. Perincian diagram use case meliputi perincian obyek, operasi dan atribut yang bersangkutan, serta relasi yang dihasilkan dari setiap objek. Class Diagram dapat dilihat pada gambar 3

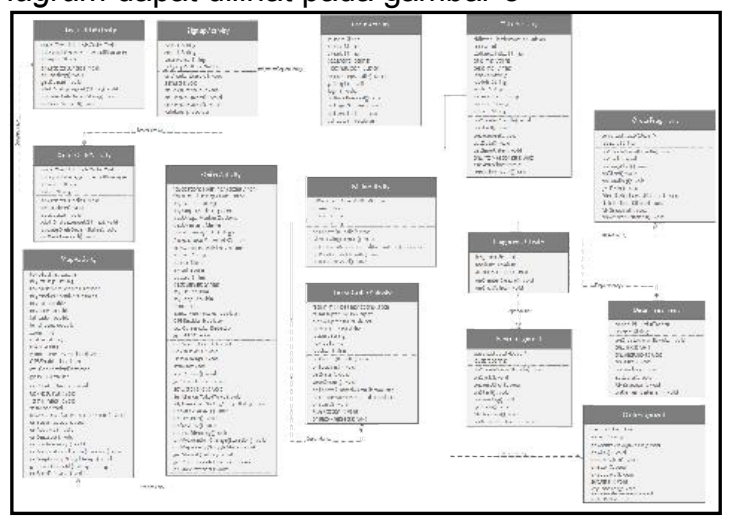

Gambar 3. Class Diagram

\subsubsection{Sequence Diagram}

Interaksi antar objek di dalam dan di sekitar aplikasi digambarkan dalam diagram sequence. Use case dianalisis satu persatu langkah-langkah atau proses yang terjadi di dalam use case tersebut sehingga menghasilkan diagram sequence seperti berikut : 


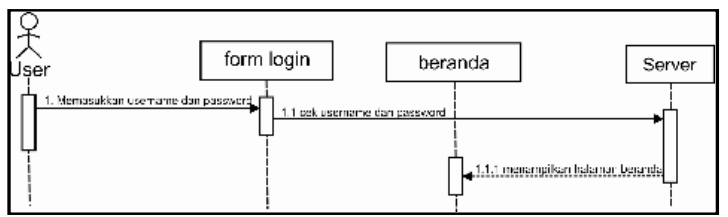

Gambar 4. Sequence Diagram Proses Login

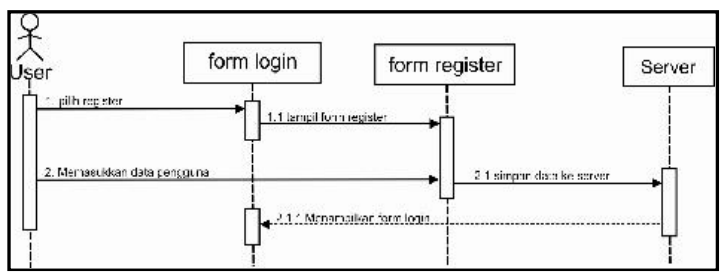

Gambar 5. Sequence Diagram Proses Registrasi

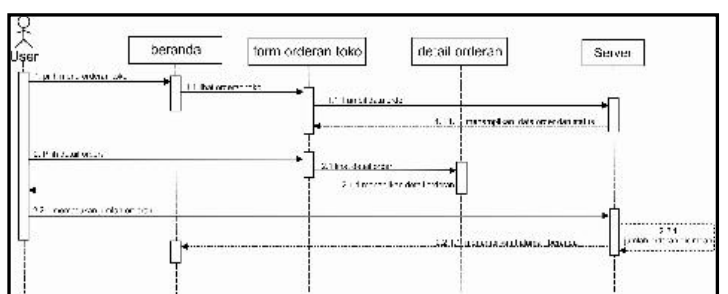

Gambar 6. Sequence Diagram Proses Lihat Orderan took

\subsubsection{Activity Diagram}

Berdasarkan pada use case diagram (gambar 2), Aplikasi pencarian oleh-oleh berbasis android memiliki beberapa aktifitas atau kegiatan. Beberapa Activity Diagram dapat dijelaskan sebagai berikut:

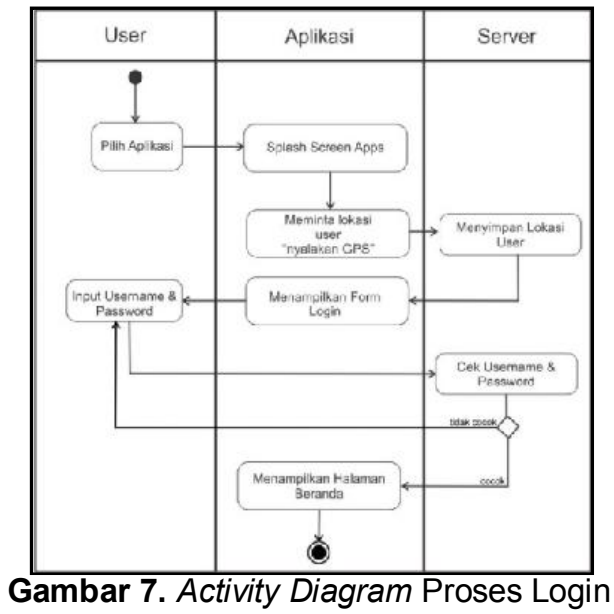

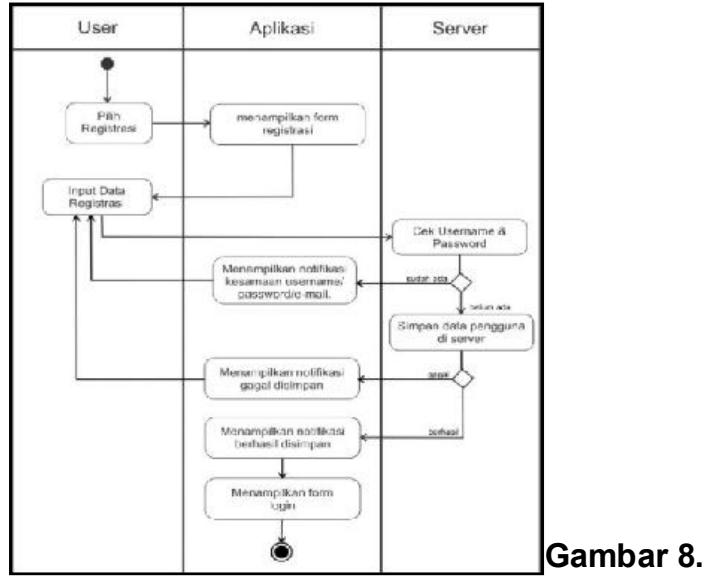

Activity Diagram Proses Registrasi 


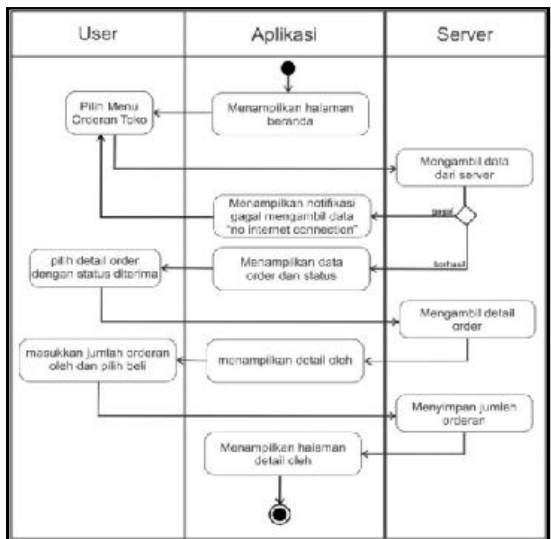

Gambar 9. Activity Diagram Proses Lihat Orderan Toko

\subsection{Perancangan Basis Data}

Dalam perancangan basis data, digambarkan tabel-tabel yang dibutuhkan dalam aplikasi layanan informasi perkuliahan mahasiswa berbasis mobile. Perancangan basis data meliputi tiga tahap, yaitu perancangan Entity Relationship Diagram (ERD), perancangan tabel, dan relasi antar tabel.

\subsubsection{Perancangan ERD}

Perancangan aplikasi pencarian toko oleh-oleh jogja berdasarkan rute perjalanan berbasis mobile menggunakan ERD dapat dilihat pada gambar 10.

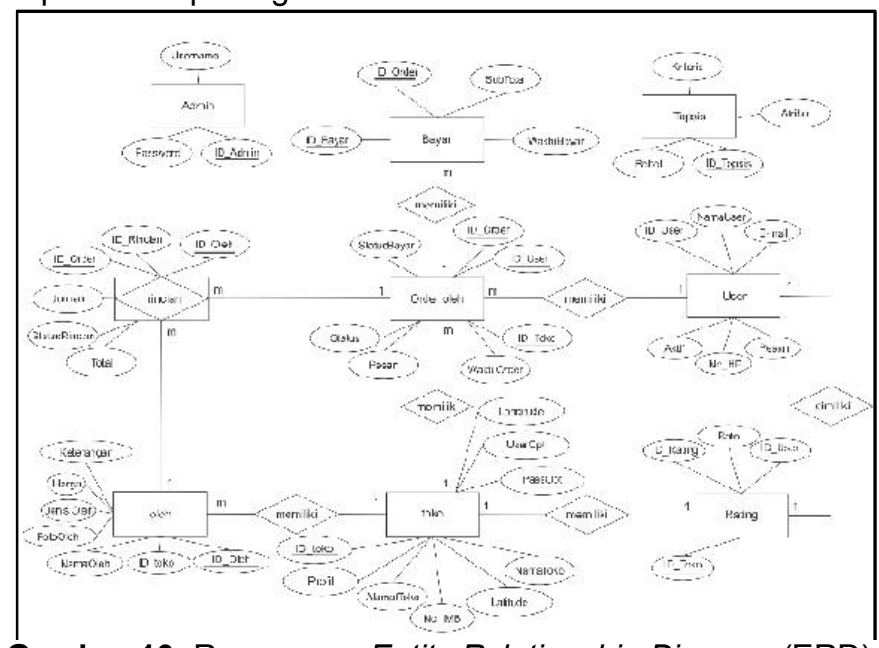

Gambar 10. Rancangan Entity Relationship Diagram (ERD)

\subsubsection{Perancangan Relasi Antar Tabel}

Perancangan relasi antar tabel aplikasi toko oleh-oleh khas jogja berdasarkan rute perjalanan berbasis mobile dapat dilihat pada gambar 11. 


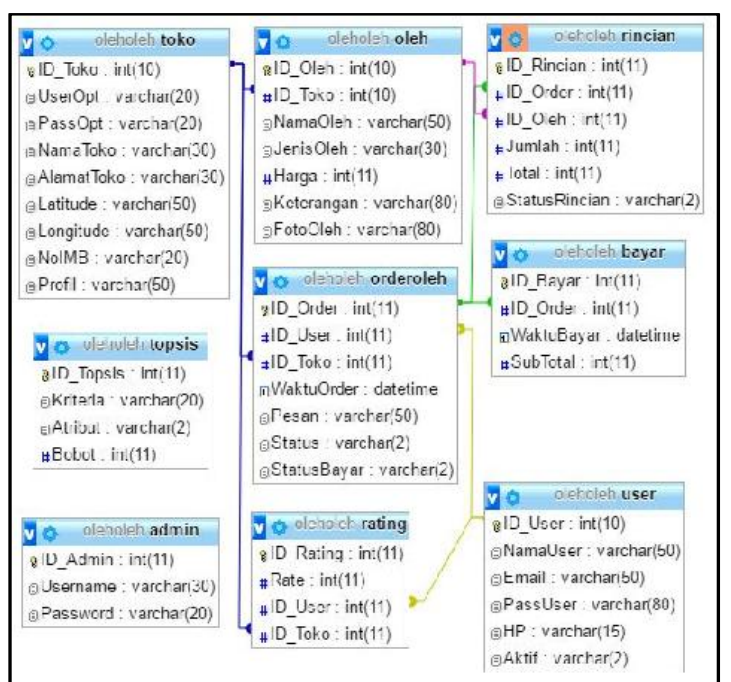

Gambar 11. Rancangan Relasi Antar Tabel

\section{IMPLEMENTASI}

\subsection{Perangkat Keras yang Digunakan}

Penyelesaian program ini dibuat dengan didukung oleh komponen perangkat keras dengan spesifikasi sebagai berikut :

1. Komputer Pesonal dengan processor Intel(R) Core(TM) i3.

2. RAM 4 GB.

3. Handphone dengan sistem operasi Android

\subsection{Perangkat Lunak yang Digunakan}

Untuk merancang aplikasi ini dibutuhkan beberapa perangkat lunak pendukung. Rincian kebutuhan antara lain:

1. Sistem Operasi yang digunakan adalah Microsoft Windows 8.1 Pro 64-bit.

2. Database menggunakan MySql.

3. Bahasa Pemograman yang digunakan adalah Java dan PHP.

4. Program yang digunakan untuk membangun aplikasi adalah Android Studio IDE dan NetBeans IDE.

\subsection{Implementasi Aplikasi Pada Sisi Client}

Pada implementasi aplikasi disisi client disajikan implementasi dari aplikasi implementasi topsis pada pencarian toko oleh-oleh khas jogja berbasis android yang berupa tampilan tiap-tiap jendela program beserta source code-nya.

1. Halaman Login. Halaman login merupakan halaman yang muncul pertama kali saat pengguna menjalankan aplikasi. Pada halaman login terdapat text input e-mail dan password. Pengguna harus memiliki akun agar bisa login untuk dapat menggunakan aplikasi. Selain itu terdapat link berupa textview untuk membuat akun. Tampilan halaman login dapat dilihat pada gambar 12 .

2. Halaman Beranda. Halaman beranda merupakan halaman untuk melihat oleh-oleh yang telah tersimpan di database. Tampilan halaman beranda dapat dilihat pada gambar 13. 


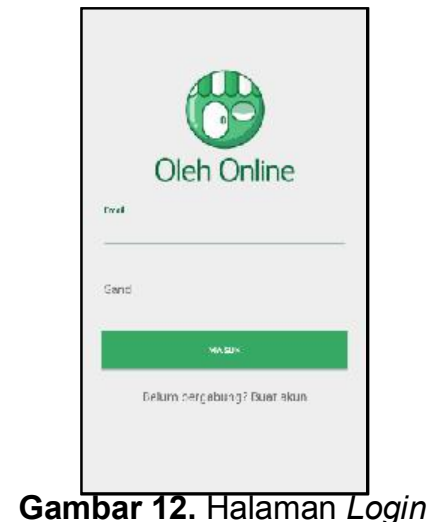

3. Halaman Buat Order. Halaman buat order merupakan halaman untuk melakukan order oleh-oleh, dan proses perhitungan TOPSIS dilakukan saat order sedang berlangsung. TOPSIS akan memberikan alternative toko terbaik. Toko terbaik akan mendapatkan logo best seller. Tampilan halaman buat order dapat dilihat pada gambar 14 dan gambar 15.

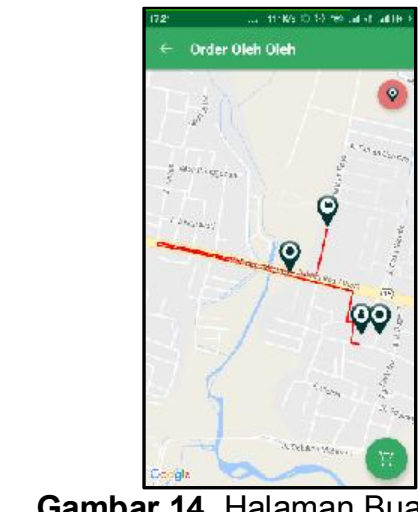

Gambar 14. Halaman Buat Order

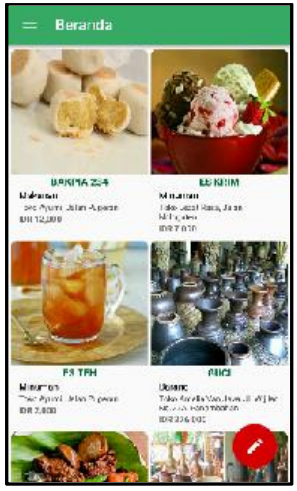

Gambar 13. Halaman Beranda

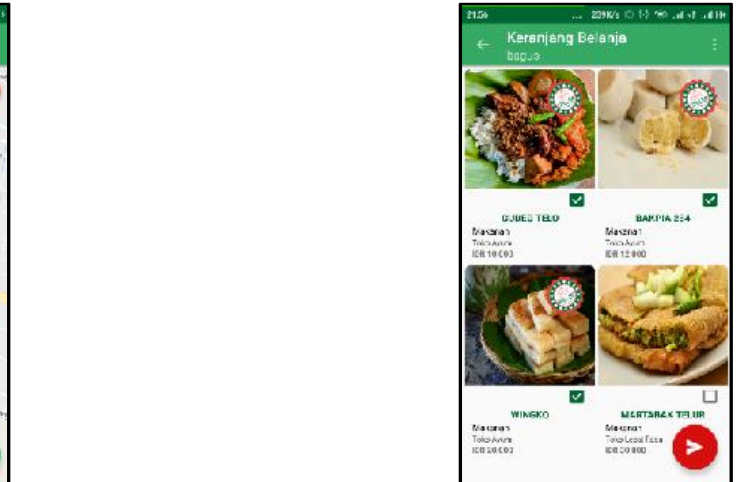

Gambar 15. Halaman Buat Order

\subsection{Implementasi Aplikasi Pada Sisi Server}

Pada implementasi aplikasi disisi server, disajikan implementasi dari aplikasi implementasi topsis pada pencarian toko oleh-oleh khas jogja berbasis android yang berupa tampilan tiap-tiap jendela program beserta source code-nya.

1. Halaman Login. Halaman login merupakan halaman input data pengguna yaitu admin dan operator toko. Tampilan halaman login dapat dilihat pada gambar 16

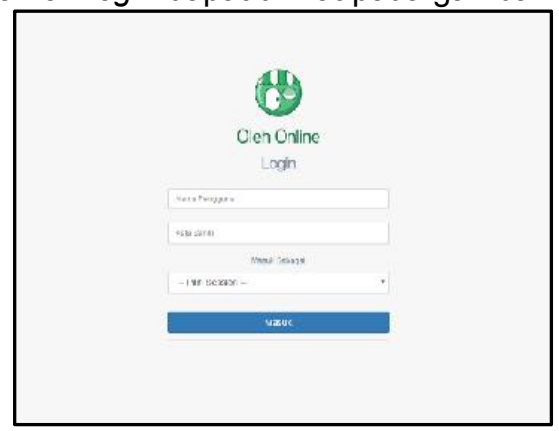

Gambar 16. Halaman Login

2. Halaman Data Oleh-oleh. Halaman data oleh-oleh merupakan halaman data oleh-oleh yang ada di dalam database toko. Tampilan halaman data oleh-oleh dapat dilihat pada gambar 17. 


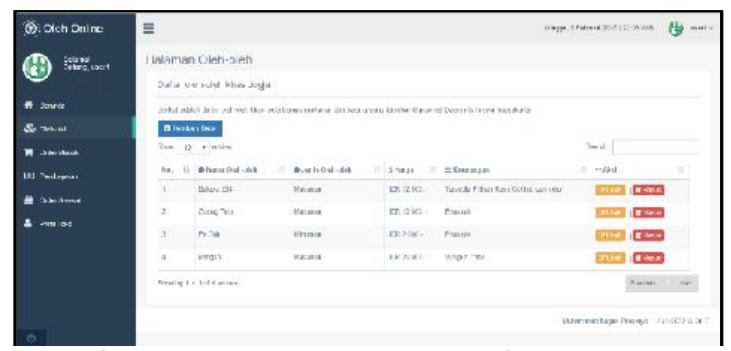

Gambar 17. Halaman Data Oleh-oleh

\section{KESIMPULAN DAN SARAN}

Berdasarkan hasil penelitian yang dilakukan, dapat diambil kesimpulan bahwa aplikasi mobile dapat membantu pengguna yaitu wisatawan untuk mendapatkan oleh-oleh berupa makanan atau barang, karena para pengguna melakukan pencarian toko oleh-oleh dan pemesanan secara langsung. Selain itu dengan mengimplementasi metode TOPSIS (Technique For Others Preference by Similarity to Ideal Solution), para pengguna mendapatkan pendukung keputusan untuk memilih oleholeh berdasarkan kriteria yga ada.

Dari penelitian yang telah dilakukan berbagai masalah yang dapat diselesaikan telah dijelaskan pada bagian kesimpulan. Tetapi pengembangan dari sistem ini juga masih memiliki banyak kekurangan. Oleh karena itu, masukan yang mungkin dapat diterapkan untuk pengembangan sistem lebih lanjut adalah sebagai berikut:

1. Sistem akan menjadi lebih efektif apabila pada metode sistem pendukung keputusan dapat menggunakan penggabungan metode, seperti metode TOPSIS (Technique For Others Preference by Similarity to Ideal Solution) dengan metode AHP (Analitycal Hierarchy Process), atau metode-metode sistem pendukung keputusan yang lain.

2. Agar sistem menjadi efektif tambahkan kriteria perhitungan TOPSIS untuk produk barang, berupa harga, kualitas barang, dll.

3. Sistem akan menjadi lebih efektif apabila menambahkan fitur-fitur yang lebih menunjang proses jual-beli secara online.

4. Semakin beragamnya sistem operasi pada smartphone saat ini, alangkah lebih baik apabila sistem ini tidak hanya dapat berjalan pada Android tetapi juga pada sistem operasi yang lainnya.

\section{DAFTAR PUSTAKA}

Github Google Maps, 2016, Class PolyUtil. http://googlemaps.github.io/android-mapsutils/javadoc/com/google/maps/android/PolyUtil.html Diakses Pada 19 Mei 2016.

Google Maps APIs, 2016, Maps Android API https://developers.google.com/maps /documentation/android-api/utility/. Diakses Pada 19 Mei 2016.

Mahdia, Faya; dan Noviyanto, Fiftin, 2013, Pemanfaatan Google Maps API untuk Pembangunan Sistem Informasi Manajemen Bantuan Logistik Pasca Bencana Alam Berbasis Mobile Web (Studi Kasus : Badan Penanggulangan Bencana Daerah Kota Yogyakarta, Yogyakarta: Jurnal Sarjana Teknik Informatika Universitas Ahmad Dahlan

Mulyadi. 2010. Membuat Aplikasi Untuk Android. Multimedia Center Publishing. Yogyakarta

Rahmayani A. dan Isa Irawan M., 2016. Perancangan dan Implementasi Perangkat Lunak Sistem Pendukung Keputusan Multi Kriteria Menggunakan Metode TOPSIS. Surabaya : Jurnal Sains dan Seni ITS 2:2337-3520.

Schmuller, Joseph. 1999. Sams Teach Yourself UML in 24 Hours.Pearson Education, Inc.

Susanto, A. 2011. Sistem Informasi Manajemen, Konsep dan Pengembangannya. Bandung: Lingga Jaya.

Waljiyanto, 2003. Sistem Basis Data, Analisis dan Pemodelan Data. Yogyakarta : Graha IImu. 